\title{
Implications of temporal changes in forest dynamics on density, nest-site selection, diet and productivity of Tawny Owls Strix aluco in the Alps
}

\author{
LUIGI MARCHESI ${ }^{1}$, FABRIZIO SERGIO ${ }^{2 *}$ and PAOLO PEDRINI \\ ${ }^{1}$ Raptor Conservation Research Unit, Trento Museum of Natural Sciences, via Calepina 14, 38100 Trento, \\ Italy and ${ }^{2}$ Department of Applied Biology, Estación Biológica de Doñana, CSIC, Avda. de María Luisa s/n., \\ Pabellón del Perú, Apdo 1056, 41013 Seville, Spain
}

\begin{abstract}
Capsule In the areas studied, Tawny Owls showed extreme flexibility and opportunism, occupying most available vegetation types and elevations below the tree-line.

Aims To assess habitat relationships for the species so as to forecast the potential impact of habitat changes. Methods We censused a total of 321 territories in 12 study areas covering the regional variation in elevation and the associated heterogeneity in vegetation types and landscape configurations.

Results The species occupied virtually all vegetation types and landscape configurations below the tree-line. Nests were mostly located on cliffs, but also in tree cavities, buildings, and stick nests of other raptors. Density varied from 12 to 60 territories $100 \mathrm{~km}^{2}$ and mean nearest-neighbour distance from 0.7 to $1.8 \mathrm{~km}$, depending on the availability of broadleaved woodland. Compared to availability, nests were nearer to cliffs and had higher richness of habitat edges and vegetation types, which positively affected chick production. Diet composition varied widely according to habitat and was mostly dominated by Edible Dormouse Glis glis, voles and mice.

Conclusion The conservation status of the species was satisfactory. Future habitat changes may favour an increase in density. Silvicultural practices encouraging more old trees with large cavities would further favour this opportunistic species.
\end{abstract}

TAWIY OWLS STRIX ALUCO ARE GENERALIST MOCTURIAL RAPTORS WIDELY DISTRIBUTED THROUGHOUT THE PALEARCTIC, WITH HIGHER ABUNDANCE II THE TEMPERATE WOODLAND ZONE (PETTY $*$ SAUROLA 1997). THOUGH OFTEI CONGIDERED A FOREST OWL, THEY HAVE SHOWI REMARKABLE ADAPTABILITY AND OPPORTUNISM, READILY COLONIZING URBAN HABITATS, FORESTRY PLANTATIONS AND INTENSIVELY CULTIVATED AREAS WITH FEW TREES (REDPATH 1995, PETTY \& SAUROLA 1997). THE SPECIES HAS BEEI THE SUBJECT OF MANY INTENSIVE INVESTIGATIONS, MOSTLY FOCUSING ON DIET COMPOSITION AND THE RELATIONSHIP BETWEEN DEXSITY, PRODUCTIVITY AND PREY AVAILABILITY (SOUTHERI 1970, DELMÉE IT AL. 1978,

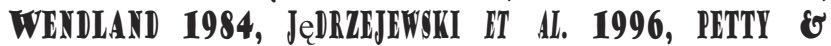
FAWKES 1997, PETTY 1999, GALEOTTI 2001). ONLY A FEW STUDIES HAVE FOCUSED OI HABITAT SELECTIOI AND MOST OF THEM WERE CONDUCTED IN URBAN AREAS OR INTENSIVE FARMLAND (GALEOTTI 1990, HARDY 1992, REDPATH 1995, PETTY

*Correspondence author.

Email: fabrizio.sergio8@tin.it
1989). OVERALL, RESEARCH IN MOUNTAIN ENVIRONMENTS HAS BEEN VERY SPORADIC.

IN ITALI, THE PPECIES IS WIDELI DISTRIBUTED THROUGHOUT THE CENTRALNORTHERI PART OF THE PEXINSULA (PETTY $\approx$ SAUROLA 1997). APART FROM SCATTERED DATA ON DENSITY (SASCOR IT AL. 1999, VREZEC 2003) AND DIET (BOUVIER \& BAYLE 1989), NO COMPREHEYSIVE STUDIES HAVE BEEN PUBLISHED FOR ANY AREA OF THE ALPS, EITHER IN ITALY OR IN ADJACENT COUNTRIES, FURTHERMORE, ALPINE FORESTS ARE CURREITLY IN A VERY DYNAMIC STATE. MUCH COPPICE. MANAGED WOODLAND IS RAPIDLY CONVERTING TO HIGH FOREST, WHILE LAND ABANDONMENT IS CAUSING PROGRESSIVE WOODLAND EXPAISIOI AT THE EXPEXSE OF GRASSLAND (PEDRINI $\forall$ SERGIO 2002, SERGIO ET AL. 2005), LEAVIYG AI URGEIT NEED FOR STUDIES ON WOODLAND SPECIES SO AS TO FORECAST THE POTEXTIAL FUTURE IMPACT OF SUCH LANDSCAPE CHANGES. HERE, WE REPORT DATA ON DENSITY, NESTSITE SELECTIOI, DIET AND PRODUCTIVITY FOR 12 TAWNY OWL POPULATIONS OF THE CENTRALEASTERI ITALIAI ALPS. 
STUDY AREAS

TAWIY OWLS WERE INTENGIVELY SURVEYED BETWEEN 2002 AND 2004 II A $55 \mathrm{KM}^{2}$ STUDY AREA IOCATED ON MOUNT BALDO IN THE TRENTO REGIOI OF CENTRALEASTERI ITALIAN ALPS (FIG, 1), ELEVATION RANGED FROM $200 \mathrm{TO} 1560 \mathrm{M}$ ASL, THE LANDSCAPE WAS CHARACTERIZED BY FORESTED MOUNTAIN SLOPES INTERSPERSED WITH VINEYARDS AT LOWER ELEVATION AND MANAGED GRASSLAND AT MIDDLE ELEVATIONS. CLIFF AVAILABILITY WAS HIGH THROUGHOUT THE STUDY AREA GIS ANALYSIS OF DATA FROM CEC (1993) REVEALED THAT 53\% OF THE AREA WAS COVERED BY WOODLAND, 23\% BY FARMLAND, $8 \%$ BY MANAGED GRASSLAND, $7 \%$ BY ALPINE MEADOWS ABOVE THE TREE'LINE, 7\% BY SHRUB VEGETATION AND $2 \%$ BY URBAI AREAS. WITH INCREASIIT ELEVATION, WOODLAND TENDED TO BE DOMINATED BY gUERCUS-TILIA ACER SPECIES, FAGUS-ABIES SPECIES AND PICEA SPECIES. IN WOODLAND AREAS, 75\% WAS MANAGED aS COPPICE (MATTHEWS 1989), MOST OF WHICH WAS AT LOWER ELEVATIOI, AND $25 \%$ WAS HIGH FOREST, MOST OF WHICH WAS AT HIGHER BLEVATIOI. IN 2002 AND 2003, TAWNY OWLS WERE CENSUSED IN ANOTHER 11 QUADRATS OF $100 \mathrm{KM}^{2}$ SCATTERED THROUGHOUT THE TRENTO REGION (FIG, 1), AND SELECTED TO COVER THE REGIONAL VARIATION IN ELEVATION AND LANDSCAPE COMPOSITION.

METHODS

TERRITORIAL PAIRS WERE CENGUSED BETWEEN OCTOBER AND FEBRDARY BY LISTENING TO SPONTANEOUS VOCALIZATIONS AND BY ELICITIYG TERRITORIAL CALLS BY BROADCASTING CONSPECIFIC VOCALIZATIONS WITH A PORTABLE TAPE'RECORDER (JęDRZEJEWSKI IT AL. 1996). IN EACH STUDY AREA, WE PLOTTED A NETWORK OF IISTENING STATIONG, LOCATED 300-500 M APART DEPENDING ON LOCAL TOPOGRAPHY AND ACOUSTICS, SO AS TO COVER THE WHOLE AREA, ALL PLOTS WERE SURVEYED AT LEAOT THREE TIMES BETWEEN OCTOBER AND FEBRUARY AND A TERRITORY WAS DEFINED AS OCCUPIED IF TERRITORIAL CALLS WERE HEARD ON AT LEAST TWO VISITS WITH MORE THAI 30 DAYS IN BETWEEN.

IN THE MOUNT BALDO INTENGIVE STUDY AREA, WE PUT MAXIMUM BFForT IITO TRYIIS TO IOCATE IESTS OF ALL PAIRS. ONCE AI OCCUPIED TERRITORY WAS FOUID, IT WAS REPEATEDLY VISITED AT NIGHT TO OBSERVE PREY DELIVERIES AT THE NEST, AND DURING THE DAY TO CHECK POTENTIAL NEST'SITES ON TREES, CLIFFS OR BUILDINGS. IF YO NEST WAS FOUND, WE CHECKED THE TERRITORY DURING JUNE AND JULY TO LISTEI FOR PERSISTENT FOOD-BEGGING CALLS OF THE FLEDGED YOUNG (SOUTHERI 1970, WENDLAND 1984, RANAZLI IT AL. 2000). IF NO SUCH CALLS WERE HEARD IN AT LEAST THREE SUCCESSIVE VISITS MORE THAI 40 DAYS APART, THE PAIR WAS ASSUMED TO HAVE FAILED, PELLETS AND PREY REMAINS FOUND UNDER NESTS AND ROOST. SITES WERE COLLECTED DURING EACH VISIT
(MARCH JULY), PREY WERE IDENTIFIED TO GENUS OR SPECIES LEVEL BY COMPARISON WITH THE PRIVATE REFEREXCE COLLEC TIOI OF L. MARCHESI, PELLETS AND REMAINS WERE POOLED ASSUMING THE MINIMUM NUMBER OF PREY'INDIVIDUALS, SO AS TO MINIMILE BIASES ASSOCIATED WITH EACH METHOD (MARCHESI UT AL. 2002).

GIS and statistical analysis

WE BMPIOYED IOGISTIC REGREGSION (TABACHNICK \& FIDELL 1996) WITH A STEPWISE PROCEDURE TO ANALYSE THE ENVIRONMENTAL FACTORS (APPENDIX) DISCRIMINATING BETWEDI THE 33 OWL TERRITORIES (I,E. ONE RANDOMLY CHOSEN NEST USED WITHIN EACH TERRITORY) CENGUSED IN THE BALDO AREA AND 33 IOCATIONS RANDOMLY PIOTTED WITHII THE BALDO AREA, ALL RANDOM LOCATIONS WERE GENERATED BY MEANS OF THE EXTENSION ANIMAL MOVEMENT OF THE GIS SOFTWARE ARCVIEW 3.2 (HOOGE \& HICHENLAUB 1997). BECAUSE TAWNY OWLS IN OUR AREA IEST IN (LIFF, TREES AND BUILDIYGS (GEE RESULTS), RANDOM LOCATIONS WERE PLOTTED IN EgUAL PROPORTIONS ON SIMILAR STRUCTURES. THE LATTER WERE ALSO VISITED IN THE FIELD AND RETAINED AS RANDOM LOCATIONS ONLY IF JUDGED TO BE POTENTIALLY SUITABLE FOR NESTING OWLS, BASED ON FAMILIARITY WITH THE SPECIES IN THE REGION. IN ADDITION, BECAUSE TAWNY OWLS ARE TERRITORIAL AND SOLITARI NESTERS, THE MINIMUM NEAREST-NEIGHBOUR DISTANCE (NND) AMONG RANDOM LOCATIONS WAS SET TO BE THE SAME AS THE MINIMUM NND AMONG OWL TERRITORIES, FIMALLY, RANDOM IOCATIONS WERE PIOTTED ONLY IN THE SAME RANGE OF ELEVATIONG RECORDED FOR OWL TERRITORIES.

THE VARIABLES (APPENDIX 1) WERE MEASURED IN THE FIELD, BY ACCESSING GIS LAND USE MAPS (CEC 1993, SERVIZIO FORESTE 1999) OR BY DIGITIZING I-M-RESOLUTION, AERIAL COLOUR PHOTOGRAPHS (COURTESY OF PROVINCIA AUTONOMA DI TRENTO, PERMIT IGM N.278 OF 30 JUNE 2000). THE VARIABLES WERE CHOSEI TO MEASURE: (1) THE CHARACTERISTICS OF THE NESTSITE AND ITS IMMEDIATE SURROUNDINGS (WITHIN A RADIUS OF $100 \mathrm{M}$ ); (2) THE DISTANCE TO POTENTIAL HUVTING GROUNDS OR TO SOURCES OF HOMAN DISTURBAICE; AND (3) HabITAT STRUCTURE AND COMPOSITION WITHIN $330 \mathrm{M}$ OF THE NEST, WHICH IS ROUGHLY HALF THE N N D IN OUR POPULATION. TO REDUCE COLLINEARITY AND THE NUMBER OF VARIABLES PRESENTED TO LOGISTIC MODELS, WE EMPLOYED THE METHOD OF VARIABLE REDUCTIOI PROPOSED BY GREEN (1979) AND COMMONLY EMPLOYED IN HABITAT SELECTION STUDIES (SERGIO \& BogLIANI 2000, SERGIO ET AL. 2003A). IN THIS METHOD, PAIRS OF INTER CORRELATED VARIABLES $(\mathbb{R}>$ 0.6) aRE CONGIDERED AS ESTIMATES OF A SINGLE UNDERLYING FACTOR, ONLY THE ONE LIKELY TO BE PERCEIVED AS MORE IMPORTANT BY THE STUDY ORGANISM If RETAINED FOR ANALYSIS. OF THE REMAINIYG 
VARIABLES, ONLY THOSE FOR WHICH HIGH UIIVARIATE DIFFER ENCES $(P<0.1)$ WERE DETECTED BETWEEN NEST SITES AND RANDOM IOCATIONS WERE INCLUDED IN MULTIVARIATE AIALYSES. THE LOGISTIC MODEL WAS VALIDATED BY APPLYING IT ON 30 OHL TERRITORIES AND 30 RANDOM IOCATIONS FROM THE RUMO STUDY AREA AND ITS SURROUNDINGS, IE. THE FAR' THEGT FROM THE BALDO PLOT (FIG, I).

TO GAII A DEEPER UNDERSTANDING OF OWL HABITAT QUALITY AND TO TEST WHETHER THE OBSERVED HABITAT CHOICES WERE ADAPTIVE (SERGIO IT AL. 2003A, 2003B), WE USED MULTIPLE REGRESSION (SOKAL \& ROHLF 1981) TO RELATE BREEDING SUCCESS (MEAI NUMBER OF FLEDGED YOUNG AVERAGED ACROSS YEARS FOR EACH TERRITORY) TO THE VARIABLES PRESENTED TO THE PREVIOUS HABITAT SELECTION MODELS. WE ADDED TO THE SET OF EXPLAMATORY VARIABLES A FACTOR VARIABLE WITH TWO LEVELS ( 1 = TERRITORY DOMINATED BY COPPICE-MANAGED WOODLAND; 2 = TERRITORI DOMINATED BY HIGH FOREST); THIS WAS CONGIDERED AS A POTENTIAL DETER MINANT OF BREEDING SUCCESS, AND ALSO TESTED THE POTENTIAL IMPACT ON OWL PRODUCTIVITY OF THE ONGOIYG CONVERSION OF COPPICE WOODLAND TO HIGH FOREST.

FINALLY, TO INVEGTIGATE THE OWL HaBITAT RELATIONSHIPS AT A LARGER SPATIAL SCALE, WE CORRELATED OWL DENSITY IN EACH OF THE 12 STUDY AREAS WITH THE FOLIOWING VARIABLES: MEAN ELEVATION OF THE STUDY AREA (CALCULATED WITH A GIS, BASED ON A 10.M-RESOLUTION DIGITAL BLEVATIOI MODEL);
RUGGEDNESS INDEX (NUMBER OF CONTOUR LINES CROSSED BY TWO 1-KM IORTH-SOUTH AND EAST-WBST TRANSECTS, AVERAGED ACROSS THE WHOLE STUDY AREA); THE PERCENTAGE OF THE AREA COVERED BY URBAI AREAS, FARMLAND, GRASSLAND, WATER, SHRUB VEGETATION, ROCKY OUTCROPS, BROADLEAVED FOREST, CONIFER FOREST, MIXED BROADLEAVED AND CONIFER FOREOTS, TOTAL WOODLAND, WOODLAND MANAGED AS COPPICE, AND WOODLAND MANAGED AS HIGH FOREST; AND THE SHANMON INDEX OF HABITAT DIVERSITY (KREBS 1998).

REGULARITY OF NEST SPACING WAS ASSESSED BY MEANS OF THE GSTATISTIC (BROWI 1975), CALCULATED AS THE RATIO OF THE GEOMETRIC TO THE ARITHMETIC MEAI OF THE SOUARED NNDS. THE INDEX RANGES FROM O TO $I$ AND VALUES ABOVE

0.65 INDICATE A REGULAR DISPERSIOI OF IESTNITES. IN ALL ANALYSE, MEAIS ARE GIVEN $\pm \mathbf{I}$ SE, TEOTS ARE TWO-TAILED, AND STATISTICAL SIGNIFICANCE WAS SET AT $\alpha \leq 0.05$. WHEN MULTIPLE TEGTS WERE PERFORMED ON THE SAME DATA SET, THE SEQUENTIAL BONEERRONI CORRECTION WAS USED TO ADJUST THE SIGNIFICAYIC LEVEL,

RESULTS

Density, nest dispersion and productivity

WE CENSUSED 33 OWL TERRITORIES IN THE BALDO AREA, CORRESPONDING TO A DENGITY OF 60 PAIRS/100 KM² (TABLE

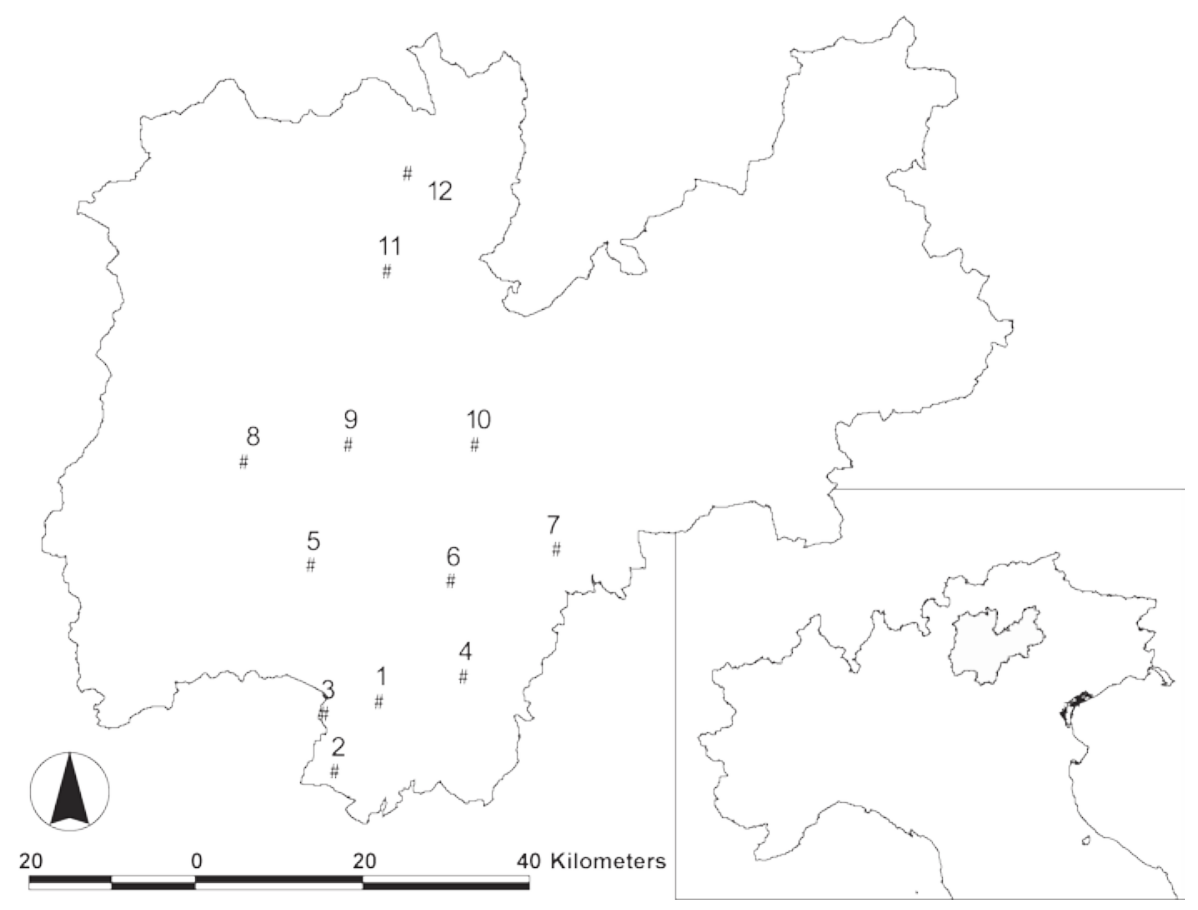

Figure 1. Location of 12 Tawny Owl study areas in the Trento region (depicted in grey in the inset) of the central-eastern Italian Alps. Each point represents the baricentre of a $100 \mathrm{~km}^{2}$ quadrat. 1, Baldo study area; 2, Lavacchio; 3, Varagna; 4, Vallarsa; 5, Sarca Valley; 6, Calliano; 7, Caldonazzo; 8, Bleggio; 9, Molveno; 10, Adige Valley; 11, Noce Valley; 12, Rumo. 
Table 1. Density, nest dispersion and productivity of a Tawny Owl population in the Mount Baldo study area (central-eastern Italian Alps, 2002-2004).

\begin{tabular}{|c|c|c|c|c|}
\hline \multirow[b]{2}{*}{ Variable } & \multirow[b]{2}{*}{2002} & \multicolumn{2}{|l|}{ Year } & \multirow[b]{2}{*}{ Grand mean } \\
\hline & & 2003 & 2004 & \\
\hline Density (territories/100 km²) & 60.0 & 60.0 & 60.0 & 60.0 \\
\hline Mean NND (m) & $684.9 \pm 67.3$ & $694.1 \pm 67.9$ & $653.4 \pm 55.4$ & $677.5 \pm 36.5$ \\
\hline G-test & 0.692 & 0.687 & 0.696 & 0.692 \\
\hline No. nests checked for reproduction & 20 & 24 & 9 & $53^{a}$ \\
\hline Mean no. fledged young/territorial pair ${ }^{b}$ & $1.90 \pm 0.28$ & $1.17 \pm 0.26$ & $1.44 \pm 0.38$ & $1.49 \pm 0.17(53)$ \\
\hline Mean no. fledged young/successful pair ${ }^{b}$ & $2.38 \pm 0.22(16)$ & $1.87 \pm 0.29$ & $1.63 \pm 0.37(8)$ & $2.03 \pm 0.17$ (39) \\
\hline Successful pairs (\%) & 80.0 & 62.5 & 88.9 & 73.6 \\
\hline
\end{tabular}

aTotal number of nests checked. ${ }^{b}$ The variations in sample size among the three years of study reflect sampling effort and not the breeding effort of the population.

Table 2. Density and nest spacing of Tawny Owls in 12 studyareas of the Trento region (central-eastern Italian Alps, 2002-2003).

\begin{tabular}{|c|c|c|c|c|c|c|}
\hline Study area & $\begin{array}{l}\text { No. of } \\
\text { territories }\end{array}$ & $\begin{array}{c}\text { Mean territory } \\
\text { elevation }(m)\end{array}$ & $\begin{array}{c}\text { Density } \\
\text { (territories } / 100 \quad \mathrm{~km}^{2} \text { ) }\end{array}$ & $\begin{array}{c}\text { Mean } \\
N N D(m)\end{array}$ & $\begin{array}{l}\text { Range of } \\
\text { NNDs }\end{array}$ & G-test \\
\hline Baldo & 33 & $710.3 \pm 37.3$ & 60.0 & $677.5 \pm 36.5$ & $360-1912$ & 0.69 \\
\hline Lavaccchio & 49 & $968.0 \pm 96.9$ & 49.0 & $1001.0 \pm 109.0$ & $550-1730$ & 0.81 \\
\hline Varagna & 60 & $1110.0 \pm 62.5$ & 60.0 & $766.0 \pm 50.9$ & $390-1020$ & 0.87 \\
\hline Vallarsa & 23 & $772.0 \pm 53.2$ & 23.0 & $1397.3 \pm 186.8$ & 490-2910 & 0.63 \\
\hline Sarca Valley & 28 & $690.9 \pm 35.0$ & 28.0 & $1179.1 \pm 153.3$ & $520-1610$ & 0.68 \\
\hline Calliano & 15 & $725.0 \pm 75.4$ & 15.0 & $2056.0 \pm 160.0$ & $1460-2860$ & 0.90 \\
\hline Caldonazzo & 12 & $780.8 \pm 68.3$ & 29.0 & $1181.7 \pm 162.1$ & $490-2250$ & 0.67 \\
\hline Bleggio & 26 & $928.5 \pm 73.4$ & 12.0 & $1736.2 \pm 254.2$ & $870-4070$ & 0.65 \\
\hline Molveno & 15 & $865.0 \pm 50.9$ & 26.0 & $1145.0 \pm 138.9$ & $450-1730$ & 0.71 \\
\hline Adige Valley & 29 & $681.8 \pm 43.1$ & 15.0 & $1267.3 \pm 119.6$ & $450-3220$ & 0.60 \\
\hline Noce Valley & 13 & $768.2 \pm 31.2$ & 13.0 & $1272.1 \pm 178.2$ & $390-4210$ & 0.38 \\
\hline Rumo & 18 & $888.0 \pm 70.1$ & 18.0 & $1842.0 \pm 220.8$ & $820-2870$ & 0.76 \\
\hline Grand mean & 321 & $795.9 \pm 17.2$ & 27.8 & $1207.9 \pm 52.0$ & $360-4210$ & 0.70 \\
\hline
\end{tabular}

1). THERE WAS YO VARIATION AMONG YEARS IN MEAN N N D (ANOVA ON VARIABLE IOG ${ }_{1}$ TRANGFORMED, $\boldsymbol{F}_{2,93}=\mathbf{0 . 6 2}, \boldsymbol{P}=$ 0.94; TABLE 1). IN THE OTHER STUDY AREAS, DENSITY VARIED BETWEEN 12 AND 60 TERRITORIES/100 KM² (TABLE 2). THERE WAS SIGNIFICANT VARIATION AMONG AREAS IN MEAN NND (ANOVA OI LOG, TRAISFORMED VARIABLE: $\boldsymbol{F}_{11,309}=8.22, P$ $=0.0009$ ), WHICH RANGED BETWEEN 678 AND 2056 M (TABLE 2). THE G STATISTIC INDICATED A REGULAR OR IEARLY REGULAR DISPERSION OF TERRITORIES II TEV OF THE 12 AREAS.

IN THE MOUNT BALDO PLOT, THE MEAN LAYING DATE WAS 1 APRIL (RAIGE; 2 MARCH-16 APRIL; $\mathbf{S E}=2$ DAYS; $\mathbb{N}=33$ ). THIS DOES IOT IYCLUDE A POSSIBLE REPLACEMENT CLUTCH LAID ON 8 JUNE (ONE CHICK FLEDGED). THERE WAS NO VARIATION AMONG IEARS IN MEDIAN NUMBER OF YOUNG FLEDGED PER TERRITORIAL OR SUCCESSFUL PAIR (KR USKAL-WALLIS TEST, $\left.X^{2}{ }_{2}<4.42, P>0.11\right)$, OR II THE PERCENTAGE OF TERRITORIAL PAIRS WHICH SUCCESGFULLY RAISED AT LEAST ONE CHICK TO FLEDGING $\left(X_{2}^{2}=3.15, P=0.21\right)$ (TABLE 1).
Nest-site selection

OVERALL, WE FOUND 44 NESTS USED AT LEAST ONCE FOR LAYING IN THE BALDO AREA, OF THESE, 28 WERE IN CLIFF HOLES, NINE IN CAVITIES OF OLD TREES (EIGHT OF THESE IN SWEET (HESTNUST CASTANEA SATIVA), FOUR IN BUILDINGS, TWO II TREE'HOLES ORIGINALLY EXCAVATED BY BLACK WOODPECKERS DRYOCOPUS MARTIUS, AND ONE IN A STICK NEST ORIGINALLY BUILT BY COMMON BUZLARDS BUTEO BUTEO. ALL CLIFF NESTS WERE IN THE LOWER PORTIOI OF THE CLIF, AT OR BELOW THE TREL CANOPY LEVEL, AND WERE USUALLY HIDDEN BY IVY HEDERA HELIX GROWING OI THE WIIF FACE.

OF THE VARIABLES PRESENTED TO THE IOGISTIC REGREGSIOI DISCRIMINATING BETWLEN OWL NESTS AND RANDOM SITES (TABLE 3), TWO ENTERED THE FIMAL MODEL: DISTAYCE TO CLIFF $(B=-0.16 \pm 0.05$, WALD $=12.23, P=0.0001) \mathrm{AND}$ INTERSPERSION INDEX $(B=0.20 \pm 0.09$, WALD $=5.14, P=$ $0.023 ; B$ FOR CONGTANT $=1.86 \pm 1.05)$. THE MODEL 
Table 3. Environmental variables (mean \pm 1 se) measured at 33 Tawny Owl nests and at 33 random locations (Mount Baldo, central-eastern Italian Alps).

\begin{tabular}{|c|c|c|}
\hline Variable & Nest-sites & Random locations \\
\hline Elevation $(m)^{a *}$ & $710.3 \pm 37.3$ & $839.1 \pm 47.6$ \\
\hline$\%$ slope $^{a * \star}$ & $48.2 \pm 4.2$ & $30.6 \pm 3.44$ \\
\hline Ruggedness index ${ }^{a} \dagger$ & $39.3 \pm 3.0$ & $32.0 \pm 2.7$ \\
\hline$N N D(m)^{a}$ & $646.4 \pm 54.2$ & $699.1 \pm 28.3$ \\
\hline Distance to cliff $(m)^{b \star \star \star}$ & $277.2 \pm 49.4$ & $634.6 \pm 53.6$ \\
\hline Distance to tree cavity $(m)^{b}$ & $1329.7 \pm 169.9$ & $1400.9 \pm 155.1$ \\
\hline Distance to grassland $(m)^{b}$ & $131.2 \pm 28.9$ & $124.2 \pm 30.6$ \\
\hline Distance to coppice $(\mathrm{m})$ & $134.6 \pm 45.4$ & $130.6 \pm 24.6$ \\
\hline Distance to high forest (m) & $692.1 \pm 110.2$ & $538.5 \pm 92.6$ \\
\hline Distance to dirt road $(m)^{b}$ & $147.3 \pm 19.8$ & $123.6 \pm 23.3$ \\
\hline Distance to road $(m)^{b}$ & $535.5 \pm 82.7$ & $388.2 \pm 64.7$ \\
\hline Distance to building $(m)^{a}$ & $313.9 \pm 50.6$ & $256.4 \pm 39.5$ \\
\hline Cliff length $(m)^{\star}$ & $335.2 \pm 81.4$ & $101.5 \pm 65.0$ \\
\hline Isolated trees ${ }^{b}$ & $9.6 \pm 1.3$ & $7.7 \pm 1.3$ \\
\hline Edge length $(m)^{b}$ & $1664.6 \pm 199.3$ & $1170.6 \pm 144.8$ \\
\hline Open interspersion index ${ }^{b}$ & $4.2 \pm 0.6$ & $3.1 \pm 0.4$ \\
\hline Interspersion index $x^{\star \star \star}$ & $8.0 \pm 0.8$ & $5.1 \pm 0.5$ \\
\hline$\%$ coppice woodland ${ }^{c}$ & $51.7 \pm 6.3$ & $36.4 \pm 6.2$ \\
\hline$\%$ Beech coppice ${ }^{c}$ & $7.9 \pm 3.0$ & $13.1 \pm 4.9$ \\
\hline$\%$ high forest ${ }^{c}$ & $18.2 \pm 4.4$ & $18.7 \pm 5.0$ \\
\hline$\%$ broadleaved high forest ${ }^{c}$ & $0.9 \pm 0.5$ & $0.9 \pm 0.9$ \\
\hline$\%$ conifer high forest ${ }^{c}$ & $15.3 \pm 4.4$ & $17.5 \pm 5.0$ \\
\hline$\%$ broadleaved woodlandc & $54.6 \pm 6.3$ & $37.7 \pm 6.2$ \\
\hline$\%$ total woodland & $69.9 \pm 3.9$ & $55.2 \pm 5.8$ \\
\hline$\%$ urban areas ${ }^{c}$ & $3.7 \pm 2.5$ & $3.2 \pm 1.0$ \\
\hline$\%$ grasslandc* & $21.8 \pm 3.0$ & $39.2 \pm 5.2$ \\
\hline$\%$ farmland ${ }^{c}$ & $1.5 \pm 0.7$ & $1.3 \pm 0.5$ \\
\hline$\%$ rockyc** & $3.2 \pm 1.0$ & $1.1 \pm 0.7$ \\
\hline Habitat diversity & $0.57 \pm 0.20$ & $0.55 \pm 0.20$ \\
\hline
\end{tabular}

Univariate differences between the two samples were tested by means of t-tests: $\dagger 0.05<P<0.1 ; * P<0.05 ; * \star P<0.01 ; * \star \star P<0.001$. Variables in italic were presented to the logistic regression model after variable reduction (see Methods). a t-Test carried out on the variable $\log _{\mathrm{e}}$-transformed; ${ }^{b} t$-test carried out on the variable square-root transformed; ${ }^{c} t$-test carried out on the variable transformed in the arcsine square root of the proportion.

CORRECTLY RECLASGIFIED $82 \%$ OF THE OHL NESTS AND 79\% OF THE RANDOM IOCATIONS ( $80 \%$ OVERALL). WHEN VALIDATED ON THE INDEPENDENT DATA SET, THE MODEL CORRECTLY ILASSIFIED 83\% OF 30 OWL NESTS AND 87\% OF 30 RANDOM LOCATIONS.

Correlates of productivity and density

IN A MULTIPLE REGRESSION, THE ONLY PREDICTOR OF THE MEAN PRODUCTIVITY OF A TERRITORY WAS THE INTERSPERSION INDEX $\left(B=0.11 \pm 0.01, I=2.27, P=0.032, R^{2}=0.18\right)$. DENSITY IN THE 12 STUDY POPULATIONS WAS POSITIVELY RELATED TO THE EXTENT OF BROADLEAVED WOODLAND IN EACH AREA $\left(\mathrm{h}_{f}=\mathbf{0 . 7 8}, \boldsymbol{P}=\mathbf{0 . 0 4 8}\right)$. ALL OTHER RELATIONSHIPS WERE NOT SIGNIFICANT AFTER THE BONFERRONI CORRECTION.

\section{Diet}

TO DEschibe VARIaTIONS IN DIET COMPOSITION DURING THE BREEDIYG PERIOD (MARCH JULY), WE ASgIGNED TERRITORIES TO
FOUR MAIN HABITAT CATEGORIES: (1) COPPICE'MANAGED WOOD. LAND (DOMINATED MAINLY BY BEECH OR A MIXTURE OF PUBESCENT OAK QUERCUS PUBESCENS, EUROPEAN HOPHORNBEAM OSTRYA CARPINIFOLIA AND FLOWERING ASH FRAXINUS ORNUS); (2) BROADLEAVED HIGH FOREST (MOSTLY BEECH-DOMINATED); (3) MIXED HIGH FOREGT (MOSTLY COMPOSED OF BEECH AND SPRUCE); AND (4) URBAN. THE DIET WAS DOMINATED BY (1) EDIBLE DORMOUSE GLIS GIIS IN COPPICE'WOODLAND; (2) MICE, VOLES, EDIBLE DORMOUSE AND VARIOUS BIRD SPECIES IN BROADLEAVED HIGH FOREOT: (3) EDIBLE DORMOUSE, VOLES, MICE, SOUIRRELS AND VARIOUS BIRD SPECIES (ESPECIALLY TURDUS SPP.) IN MIXED HIGH FOREST; AND (4) SPARROWG, FINCHES AND PIGEONS IN URBAI AREAS (TABLL 4).

\section{DISCUSSION}

OUR REGIONAL'SCALE RESULTS CONFIRMED THE REMARKABLE FLEXIBILITY AND OPPORTUIISM PREVIOUSLI REPORTED FOR THE SPECIES AT A LARGER, CONTINENTAL SCALE (PETTY \& SAUROLA 
Table 4. Diet of Tawny Owls ( $n=29$ sampled territories) on Mount Baldo (central-eastern Italian Alps) according to four main habitat types.

\begin{tabular}{|c|c|c|c|c|c|c|c|c|c|c|c|c|}
\hline \multirow[b]{2}{*}{ Prey category } & \multicolumn{3}{|c|}{$\begin{array}{l}\text { Coppice } \\
\text { woodland }\end{array}$} & \multicolumn{3}{|c|}{$\begin{array}{c}\text { Broadleaved } \\
\text { high forest }\end{array}$} & \multicolumn{3}{|c|}{$\begin{array}{c}\text { Mixed } \\
\text { high forest }\end{array}$} & \multicolumn{3}{|c|}{$\begin{array}{l}\text { Urban } \\
\text { areas }\end{array}$} \\
\hline & $n$ & $\% n$ & $\% w$ & $n$ & $\% n$ & $\% w$ & $n$ & $\% n$ & $\% w$ & $n$ & $\% n$ & $\% w$ \\
\hline Mammals & 185 & 85.7 & 94.1 & 178 & 82.0 & 84.3 & 220 & 73.8 & 82.0 & 71 & 12.8 & 33.8 \\
\hline Edible Dormouse Glis glis & 95 & 44.0 & 81.2 & 10 & 4.6 & 23.4 & 25 & 8.4 & 30.0 & 8 & 1.4 & 4.8 \\
\hline Apodemus spp. & 56 & 25.9 & 7.1 & 132 & 60.8 & 45.8 & 50 & 16.8 & 8.9 & 37 & 6.7 & 3.3 \\
\hline Bank Vole Clethrionomys glareolus & 28 & 13.0 & 4.8 & 14 & 6.5 & 6.6 & 47 & 15.8 & 11.2 & 0 & 0.0 & 0.0 \\
\hline Common Dormouse Muscardinus avellanarius & 0 & 0.0 & 0.0 & 10 & 4.6 & 3.9 & 27 & 9.1 & 5.4 & 0 & 0.0 & 0.0 \\
\hline Brown Rat Rattus norvegicus & 0 & 0.0 & 0.0 & 0 & 0.0 & 0.0 & 0 & 0.0 & 0.0 & 14 & 2.5 & 24.9 \\
\hline Unidentified Microtinae & 6 & 2.8 & 1.0 & 5 & 2.3 & 2.3 & 40 & 13.4 & 9.6 & 0 & 0.0 & 0.0 \\
\hline Garden Dormouse Eliomys quercinus & 0 & 0.0 & 0.0 & 0 & 0.0 & 0.0 & 10 & 3.4 & 7.6 & 0 & 0.0 & 0.0 \\
\hline Red Squirrel Sciurus vulgaris & 0 & 0.0 & 0.0 & 0 & 0.0 & 0.0 & 2 & 0.7 & 5.3 & 0 & 0.0 & 0.0 \\
\hline Other mammals ${ }^{a}$ & 0 & 0.0 & 0.0 & 7 & 3.2 & 2.3 & 19 & 6.4 & 3.4 & 12 & 2.2 & 0.7 \\
\hline Birds & 23 & 10.6 & 5.9 & 28 & 12.9 & 15.6 & 45 & 15.1 & 18.3 & 475 & 85.7 & 66.2 \\
\hline House Sparrow Passer domesticus & 3 & 1.2 & 0.5 & 0 & 0.0 & 0.0 & 0 & 0.0 & 0.0 & 92 & 16.6 & 11.1 \\
\hline Chaffinch Fringilla coelebs & 6 & 2.8 & 0.8 & 7 & 3.2 & 2.6 & 4 & 1.3 & 0.7 & 69 & 12.5 & 6.6 \\
\hline Unidentified Passeriformes & 4 & 1.9 & 0.5 & 3 & 1.4 & 1.0 & 21 & 7.1 & 3.7 & 64 & 11.6 & 5.7 \\
\hline European Greenfinch Carduelis chloris & 0 & 0.0 & 0.0 & 0 & 0.0 & 0.0 & 0 & 0.0 & 0.0 & 51 & 9.2 & 6.6 \\
\hline European Goldfinch Carduelis carduelis & 1 & 0.5 & 0.1 & 2 & 0.9 & 0.6 & 0 & 0.0 & 0.0 & 43 & 7.8 & 3.1 \\
\hline Common Blackbird Turdus merula & 3 & 1.4 & 1.8 & 0 & 0.0 & 0.0 & 2 & 0.7 & 1.7 & 19 & 3.4 & 8.1 \\
\hline Mistle Thrush Turdus viscivorus & 0 & 0.0 & 0.0 & 0 & 0.0 & 0.0 & 8 & 2.7 & 8.0 & 0 & 0.0 & 0.0 \\
\hline Unidentified Turdidae & 0 & 0.0 & 0.0 & 4 & 1.8 & 7.1 & 2 & 0.7 & 1.8 & 3 & 0.5 & 1.4 \\
\hline Rock Pigeon Columba livia & 0 & 0.0 & 0.0 & 0 & 0.0 & 0.0 & 0 & 0.0 & 0.0 & 7 & 1.3 & 8.5 \\
\hline Other birds ${ }^{b}$ & 6 & 2.8 & 2.1 & 12 & 5.5 & 4.3 & 8 & 2.7 & 2.2 & 127 & 22.9 & 15.1 \\
\hline Invertebrates & 8 & 3.7 & 0.0 & 11 & 5.0 & 0.1 & 33 & 11.0 & 0.2 & 8 & 1.4 & 0.0 \\
\hline Melolontha melolontha & 0 & 0.0 & 0.0 & 0 & 0.0 & 0.0 & 32 & 10.7 & 0.2 & 0 & 0.0 & 0.0 \\
\hline Other invertebrates ${ }^{c}$ & 8 & 3.7 & 0.0 & 11 & 5.1 & 0.1 & 1 & 0.3 & 0.0 & 8 & 1.4 & 0.0 \\
\hline Total & 216 & & & 217 & & & 298 & & & 554 & & \\
\hline Mean prey mass \pm se $(\mathbf{n})^{d}$ & 73. & \pm 3.8 & 216) & 26. & \pm 1.9 & (217) & 37. & $7 \pm 2.6$ & (298) & 40.3 & \pm 2.9 & (554) \\
\hline
\end{tabular}

Prey samples were collected at 11 territories dominated by coppice woodland vegetation, eight dominated by broadleaved high forest, eight dominated by mixed high forest, and at two urban territories. Only prey groups accounting for more than $5 \%$ by number or weight in at least one habitat category are shown. $n=$ Number of items; $\% n=\%$ by number; $\% w=\%$ by live weight. alncludes: Common Shrew Sorex araneus (in order of habitat, respectively: $n=0, n=1, n=7, n=0)$; Pygmy Shrew Sorex minutus (0, 2, 0, 0); Alpine Shrew Sorex alpinus (0, 0, 6, 0); Soricidae spp. (0, 2, 3, 0); Common Mole Talpa europaea (0, 1, 3, 0); Chiroptera spp. (0, 0, 0, 4); House Mouse Mus musculus (0, 1, 0, 2); Muridae spp. (0, 0, 0, 6). 'bIncludes: Common Quail Coturnix coturnix (0, 0, 0, 1); Eurasian Scops Owl Otus scops (1, 0, 0, 0); Tengmalm's Owl Aegolius funereus (1, 0, 0, 0); Common Swift Apus apus (0, 0, 0, 7); Eurasian Wryneck Jynx torquilla (0, 0, 0, 1); Barn Swallow Hirundo rustica (0, 0, 0, 1); Eurasian Crag Martin Ptyonoprogne rupestris (0, 0, 0, 3); House Martin Delichon urbicum (0, 0, 0, 5); Pied Wagtail Motacilla alba (1, 4, 0, 23); Grey Wagtail Motacilla cinerea (0, 0, 0, 6); European Robin Erithacus rubecula (0, 0, 0, 8); Common Redstart Phoenicurus phoenicurus (0, 0, 0, 2); Song Thrush Turdus philomelos (1, 0, 2, 3); Blackcap Sylvia atricapilla (0, 0, 0, 3); Sylviidae spp. (0, 1, 0, 0); Common Chiffchaff Phylloscopus collybita $(0,0,0,1)$; Crested Tit Lophaphanes cristatus (0, 0, 4, 0); Blue Tit Cyanistes caeruleus (0, 0 , 0 , 3); Great Tit Parus major (0, 0, 0, 11); Paridae spp. (0, 5, 0, 11); Wood Nuthatch Sitta europea (0, 0, 0, 1); Red-backed Shrike Lanius collurio (0, 0, 0, 1); Common Starling Sturnus vulgaris $(0,0,0,8)$; Eurasian Tree Sparrow Passer montanus (0, 0, 0, 6); Atlantic Canary Serinus canaria (0, 0 , 0, 1); European Serin Serinus serinus (0, 0, 0, 2); Common Bullfinch Phyrrula phyrrula (0, 0, 2, 0); Hawfinch Coccothraustes coccothraustes $(0,1,0$, 1); Fringillidae spp. (2, 1, 0, 18). IIncludes: Euscorpios spp. (4, 0, 0, 0); Coleoptera spp. (3, 7, 0, 8); Anoplotrupes stercorosus (0, 1, 0, 0); Scarabeidae spp. (0, 0, 1, 0); Orthoptera spp. $(1,0,0,0)$. ${ }^{d}$ Mean mass of all the prey items in each sample (measured in $g$ ).

1997, GALEOTTI 2001). IN THE ALPS, TAWNY OWLS OCCURRED OVER AI EXTREMELY BROAD RAIGE OF ELEVATIONS (TABLL 2), FROM THE VALLEY HLOOS UP TO THE LIMIT OF THE TREE'LINE, CORRESPONDING TO A MULTITUDE OF LANDSCAPE, MICROCLIMATE AND VEGETATION TYPES. THE ABILITY TO USE A WIDE ARRAY OF NEST STRUCTURES (CLIFFS, TREES, BUILDINGS, ETC.) FURTHER FAVOURED THE COLONIZATIOI OF MOST OF THE HABITATS AVAIL ABLE II THE REGIOI, FROM URBAI AREAS TO FRAGMENTED WOODLANDS OR CONTINUOUS FORESTS VARYING IN FLORISTIC COM- POSITION AND MAIAGEMENT, FURTHERMORE, THE PROYOUICED
HABITAT'RELATED VARIATION IN DIET COMPOSITION HIGHLIGHTED THE OPPORTUVISTIC FORAGIIG TACTIC OF THIS OWL, CAPABLE OF EXPLOITIIG A WIDE SPECTRUM OF PREY, RAYGIYG FROM GROUND. DWELLING SPECIES SUCH AS VOLES AND MICE, TO ARBOREAL SPECIES SUCH AS EDIBLE DORMOUSE AND SOME BIRDS.

COMPARED TO RANDOM IOCATIOIS, TAWIY OWLS SELECTED OITES: (1) NEARER TO OLIFF, WHICH MAY PROVIDE ABUNDANT NEST-SITES WITH DIFHIULT ACCESS TO MAMMALIAI PREDATORS (INCLUDING HUMANS; SERGIO IT AL. 2003A, 2005); AND (2) WITH HIGHER RICHNESS OF HABITAT TYPES AND ECOTONES. THE 
LATTER REOULT If TO BE EXPECTED FOR VARIOUS REASOIS: (A) TAWIY OWL ARE A 'SIT'AND.WAIT' PREDATOR OFTEI EXPLOITING HABITAT EDGES (SOUTHERI \& LOWE 1968, HARDY 1992, REDPATH 1995); (B) THE OWL DIET USUALLY VARIES SEASONALLY, BEING DOMINATED IN DIFFERENT PERIODS BY PREY TYPES ASSOCIATED WITH DIFFERENT HABITATS (SOUTHERI \& LOWE 1968, WENDLAND 1984, GALEOTTI 2001); AND (C) PREY ABUNDANCE AND DIET COMPOSITION MAY VARY RADICALLY BETWEEN YEARS WITHII EACH TERRITORI, WHICH IS USUALLY OCCUPIED FOR LIFE (SOUTHERN \& LOWE 1968, PETTY \& SAUROLA 1997).

IONG'TERM AND ALLYIAR'ROUND MAINTENANCE OF AN ALV PURPOSE TERRITORY MAY PROMOTE SELECTION OF A STRUCTURALLY DIVERSE FORAGING AREA, ALLOWING FOR RAPID PREY/HABITAT SWITCHING AMONG SEASONS AND YEARS, AS ORIGINALLY POINTED OUT BY SOUTHERI \& LOWE (1968; PETTY 1989). II TURI, THIS MAY EXPLAIN WHY TERRITORIES WITH HIGHER RICHIESS OF VEGETATION TYPES AND BOUNDARIES ALSO ENJOYED HIGHER PRODUCTIVITY, WHICH FURTHER SUGGESTS THAT THE OBSERVED CHOICES WERE ADAPTIVE, AND THAT SUCH A SELECTED FEATURE WAS A COMPONENT OF TERRITORY gUALITY FOR THE OWLS. A SIMILAR PREFERENCE FOR DIVERSE AREAS RICH IN EDGES HAS BEEI REPORTED FOR OTHER GENERALIST RAPTORS (AUSTIN ET AL. 1996, MARTíNEL \& ZUBEROGOITIA 2004, SERGIO IT AL. 2005). HINALLY, THE FACT THAT TAWNY OWLS RESPONDED MORE TO THE STRUCTURE OF THE LOCAL LANDSCAPE (I.E. AVAILABILITY OF HabITAT EDGES) THAI TO ITS COMPOSI TION (FORMAN 1995) MAY FURTHER EXPLAIN THE SUCCEGSFUL COLONIZATIOI BY THE SPECIES OF SO MANY HABITAT TYPES, WHICH MAKES TAWIY OWLS PROBABLY THE MOST UBIgUITOUS RAPTORS OF THE ALPS. HOWEVER, DESPITE SUCH
FLEXIBILITY IN INDIVIDUAL HabITAT CHOICES, AT THE POP. ULATION LEVEL DENGITY WAS POSITIVELY RELATED TO THE AVAILABILITY OF BROADLEAVED WOODLAND, WHICH FURTHER CONFIRMS THE LARGE'SCALE LINK OF THIS SPECIES WITH SUCH MacROHabITAT, AS PREVIOUSLI gUaLITATIVELY REPORTED aT a CONTINENTAL SCALE (PETTY \& SAUROLA 1997).

IN COYCLUSION, TWO FEATURES OF OUR POPULATION DIFFER FROM MOST PREVIOUS STUDIES ON THIS SPECIES. FIRST, TO OUR KNOWLEDGE, THIS IS THE FIRT POPULATION STUDIED THAT HAS SUCH A HIGH FREQUENCY OF (LIFF NESTING. THIS MAY HAVE BEEN PROMOTED BY (1) THE IOW AVAILABILITY OF MaTURE TREES WITH SUITABLE CAVITIES, AND (2) THE WIDESPREAD PERSECUTION OF RAPTORS AT THE NEST WHICH OCCURRED IN THE ALPS UNTIL RELATIVELY RECENTLY. AS WELL AS BELYG WIDELY AVAILABLE IN THE ALPINE LANDSCAPE, CLIFY ARE LIKELY TO BE LESS ACCESSIBLE TO HUMANS THAN NESTS IN TREES OR BUILDINGS. SIMILAR DYIAMICS HAVE BEEN REPORTED FOR OTHER ALPINE RAPTORS (SERGIO IT AL. 2003A, 2005). SECOND, APART FROM A PREVIOUS STUDY IN THE WESTERN ALPS (BOUVIER \& BAYLE 1989), THIS If THE FIRTI POPULATION STUDIED THAT HAS A DIET DOMINATED BY EDIBLE DORMOUSE. THIO SPECIES If EXTREMELY ABUNDANT IN THE BROADLEAVED WOODLAND OF THE ALPS AND MAY REPRESENT AN IDEAL PREY GIVEI ITS RELATIVELY LARGE BODY WEIGHT AND EXTREMELY PERSISTENT YOCTURNAL VOCALIZATIONS, WHICH PROBABLY MAKE IT AN GAOY TARGET FOR a MIGHT PREDATOR EMPLOYING AUDITORY IUES FURTHERMORE, EDIBLE DORMOUSE IS MORE ABUNDANT IN COPPICE-MANAGED WOODLAND THAN IN OTHER FOREST TYPES (UNPUBL, DATA), WHICH EXPLAINS ITS HIGHER OCCURRENCE IN THE DIET OF PAIRS OCCUPYING TERRITORIES DOMINATED BY COPPICE WOODLAND (TABLE 4), THIS

Table 5. Density, nearest-neighbour distance (NND) and productivity of some Tawny Owl populations in mountainous areas of Europe (1980s and 1990s). Only study areas of more than $30 \mathrm{~km}^{2}$ are included, as smaller plots were demonstrated to yield inflated estimates of density (Galeotti 2001).

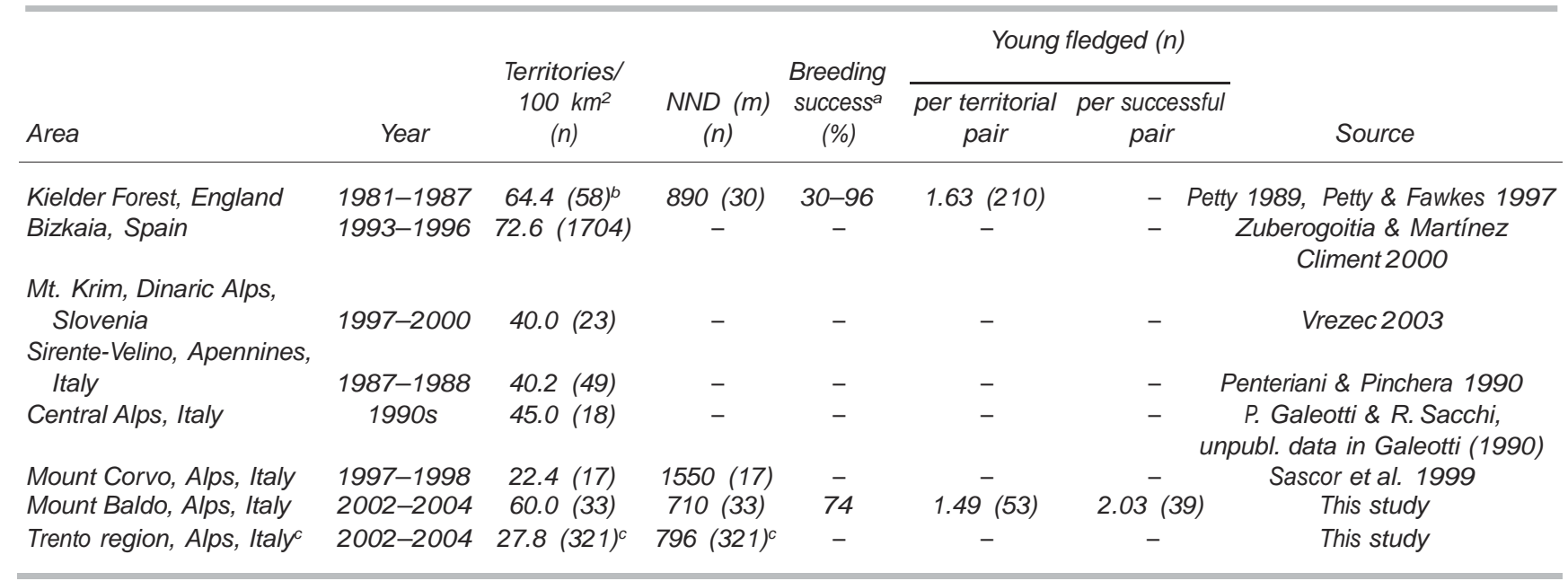

aPercentage of territorial pairs raising at least one chick to fledging age. ${ }^{b}$ Cumulative number of territories occupied at least once during a seven-year period. 'Based on the cumulated sample from 12 study areas (see Table 2). 
CONFIRMS THE WELLDEMONGTRATED PREFEREYTIAL EXPLOITA' TION OF THE MOST AVAILABLE AND PROFITABLE PREY BY THIS OPPORTUNISTIC SPECIES (gOUTHERI 1970, DELMÉE IT AL. 1978, WENDLAND 1984, JęDRZEJEWOKI bT AL. 1996, PETTY 1999).

\section{Conservation implications \\ THE COVSERVATION STATUS OF THESE POPULATIONS IS SATISFaC. TORY. POPULATIONS SEEM STABLE, BASED OI MORE THAI 30 TERRITORIES KYOWI TO BE CONTINUOUSLY OCCUPIED FOR THE PAST TEN YEARS, DENSITY WAS IN THE RANGE OF VALUES REPORTED FOR OTHER MOUNTAINOUS AREAS OF EUROPE (TABLE 5) AND PRODUCTIVITY WAS COMPARABLE TO PREVIOUSLY REPORTED ESTIMATES (SOUTHERI 1970, WENDLAND 1984, PETTY 1989, JęDRZEJEWSKI IT AL. 1996, RAMAZZI IT AL. 2000). THE ONGOING CONVERSION OF MUCH COPPICE WOOD. LAND TO HIGH FOREST IS LIKELY TO BE BENEHICLAL FOR TAWNY OWLS, WHILE THE PROGRESSIVE WOODLAND EXPANGION ASSOCIATED WITH LAND ABANDONMENT MAY FURTHER FAVOUR THE SPECIES. SILVICULTURAL PRACTICES ALLOWING HIGHER AVAILABILITY OF EDGE HABITATS AND OF MATURE OR DEAD TREES WITH LARGE CAVITIES WOULD ADDITIONALLY BENEFIT THIS OPPORTUIISTIC OWL.}

\section{ACKNOWLEDGEMENTS}

WE THANK M. LICANTROPI, G. MaRTII, V. PENTERIAII, S. J. PETTY AND AN ANONYMOUS REFERE FOR COMMENTS ON A PREVIOUS DRAFT OF THE MaNUSCRIPT. PART OF THIS STUDY WAS FUNDED BY PROJECT BIODIVERITA, FUNDED BY THE AUTONOMOUS PROVINCE OF TRENTO.

\section{REFERENCES}

Austin, G.E., Thomas, C.J., Houston, D.C. \& Thompson, B.A. 1996. Predicting the spatial distribution of buzzard Buteo buteo nesting areas using a Geographical Information System and remote sensing. J. Appl. Ecol. 33: 1541-1550.

Bouvier, M. \& Bayle, P. 1989. Le regime alimentaire de la Chouette hulotte Strix aluco dans le sud des Alpes francaises. Biévre 10: $1-22$.

Brown, D. 1975. A test of randomness of nest spacing. Wildfowl 26: 102-103.

CEC 1993. CORINE Land Cover - Guide Technique. Commission of the European Communities, Directorate-General - Environment, Nuclear Safety and Civil Protection. Office for Official Publications of the European Communities, Bruxelles, Belgium.

Delmée, E., Dachy, P. \& Simon, P. 1978. Quinze annees d'observations sur la reproduction d'une population forestiere de Chouettes hulottes (Strix aluco). Le Gerfaut 68: 590-650.

Forman, R.T.T. 1995. Land Mosaics: The Ecology of Landscapes and Regions. Cambridge University Press, Cambridge.

Galeotti, P. 1990. Territorial behaviour and habitat selection in an urban population of the tawny owl Strix aluco L. Boll. Zool. 57: 59-66.

Galeotti, P. 2001. Strix aluco Tawny Owl. BWP Update 3: 1-34.
Green, R.H. 1979. Sampling Design and Statistical Methods for Environmental Biologists. John Wiley \& Sons, New York.

Hardy, A.R. 1992. Habitat use by farmland Tawny Owls Strix aluco. In Galbraith, C.A., Taylor, I.R. \& Percival, S. (eds) The Ecology and Conservation of European Owls: 55-63. Joint Nature Conservation Committee, Peterborough.

Hooge, P.N. \& Eichenlaub, B. 1997. Movement. Animal Movement Extension to ArcView ver. 1.1. Alaska Biological Science Center, US Geological Survey, Anchorage.

Ję drzejewski, W., Ję drzejewska, B., Szymura, A. \& Zub, K. 1996. Tawny owl (Strix aluco) predation in a pristine deciduous forest (Białowieża National Park, Poland). J. Anim. Ecol. 65: 105-120.

Krebs, C.J. 1998. Ecological Methodology. Harper Collins, New York.

Marchesi, L., Pedrini, P. \& Sergio, F. 2002. Biases associated with diet study methods in the Eurasian Eagle Owl. J. Raptor Res. 36: 11-16.

Martínez, J.A. \& Zuberogoitia, I. 2004. Habitat preferences for Long-eared Owls Asio otus and Little Owls Athene noctua in semiarid environments at three spatial scales. Bird Study 51: 163-169.

Matthews, J.D. 1989. Silvicultural Systems. Oxford University Press, Oxford.

Pedrini, P. \& Sergio, F. 2002. Regional conservation priorities for a large predator: golden eagles Aquila chrysaetos in the Alpine range. Biol. Conserv. 103: 163-172.

Penteriani, V. \& Pinchera, F. 1990. Censimento di una popolazione di Allocco, Strix aluco, in un massiccio montuoso dell'Appennino centrale (Abruzzo). Riv. Ital. Orn. 60: 20-28.

Petty, S.J. 1989. Productivity and density of tawny owls Strix aluco in relation to the structure of a spruce forest in Britain. Ann. Zool. Fenn. 26: 227-233.

Petty, S.J. 1999. Diet of tawny owls (Strix aluco) in relation to field vole (Microtus agrestis) abundance in a conifer forest of northern England. J. Zool. 248: 451-465.

Petty, S.J. \& Fawkes, B.L. 1997. Clutch size variation in Tawny Owls (Strix aluco) from adjacent valley systems: can this be used as a surrogate to investigate temporal and spatial variations in vole density? In Duncan, J.R., Johnson, D.H. \& Nivholls, T.H. (eds) Biology and Conservation of Owls of the Northern Hemisphere: 315-324. USDA Forest Service, St. Paul, USA.

Petty, S.J. \& Saurola, P. 1997. Tawny Owl Strix aluco. In Hagemeijer, W.J.M. \& Blair, M.J. (eds) The EBCC Atlas of European Breeding Birds, Their Distribution and Abundance: 420-421. T \& $A D$ Poyser, London.

Ranazzi, L., Manganaro, A. \& Salvati, L. 2000. The breeding success of Tawny Owls (Strix aluco) in a Mediterranean area: a longterm study in urban Rome. J. Raptor Res. 34: 322-326.

Redpath, S.M. 1995. Habitat fragmentation and the individual: tawny owls Strix aluco in woodland patches. J. Anim. Ecol. 64: 652-661.

Sascor, R., Maistri, R. \& Noselli, S. 1999. Densità e preferenze ambientali di alcune specie di Strigiformi nel Parco Naturale Monte Corno/Alto Adige. Avocetta 23: 100.

Sergio, F. \& Bogliani, G. 2000. Hobby Falco subbuteo nest-site selection and productivity in relation to intensive agriculture and forestry. J. Wildl. Manage. 64: 637-646.

Sergio, F., Pedrini, P. \& Marchesi, L. 2003a. Adaptive selection of foraging and nesting habitat by black kites (Milvus migrans) and its implications for conservation: a multi-scale approach. Biol. Conserv. 112: 351-362.

Sergio, F., Pedrini, P. \& Marchesi, L. 2003b. Spatio-temporal shifts in gradients of habitat quality for an opportunist avian predator. Ecography 26: 243-255. 
Sergio, F., Scandolara, C., Marchesi, L., Pedrini, P. \& Penteriani, V. 2005. Effect of agro-forestry and landscape changes on common buzzards (Buteo buteo) in the Alps: implications for conservation. Anim. Conserv. 8: 17-25.

Servizio Foreste 1999. Carta Fisionomica della Copertura Forestale in Trentino. Provincia Autonoma di Trento, Trento, Italy.

Sokal, R.R. \& Rohlf, F.J. 1981. Biometry. W. H. Freeman, New York, USA.

Southern, H.N. 1970. The natural control of a population of Tawny owls (Strix aluco). J. Zool. 162: 197-285.

Southern, H.N. \& Lowe, V.P.W. 1968. The pattern of distribution of prey and predation in Tawny owl territories. J. Anim. Ecol. 37: 75-97.

Tabachnick, B.G. \& Fidell, L.S. 1996. Using Multivariate Statistics. HarperCollins, New York.

Vrezec, A. 2003. Breeding density and altitudinal distribution of the Ural, Tawny, and Boreal Owls in North Dinaric Alps (central Slovenia). J. Raptor Res. 37: 55-62.

Wendland, V. 1984. The influence of prey fluctuations on the breeding success of the Tawny Owl Strix aluco. Ibis 126: 284-295.

Zuberogoitia, I. \& Martínez Climent, J.A. 2000. Methods for surveying Tawny Owl Strix aluco populations in large areas. Biota 1: 137-146.

(MS received 15 October 2004; revised MS accepted 5 May 2005)

\section{APPENDIX}

Environmental variables measured at Tawny Owl nests and random locations.

\begin{tabular}{|c|c|}
\hline Variable & Description \\
\hline Elevation $(m)$ & Elevation of the nest above sea level \\
\hline$\%$ slope & Percentage slope within $100 \mathrm{~m}$ of the nest \\
\hline Ruggedness index & Number of contour lines crossed by two N-S and W-E transects of $660 \mathrm{~m}$ \\
\hline$N N D(m)$ & Distance to the nearest Tawny Owl territory \\
\hline Distance to cliff $(m)$ & Distance to the nearest cliff \\
\hline Distance to tree cavity $(\mathrm{m})$ & Distance to the nearest tree with potentially suitable nesting cavities \\
\hline Distance to grassland (m) & Distance to the nearest grassland field \\
\hline Distance to coppice $(\mathrm{m})$ & Distance to the nearest patch of coppice-managed woodland \\
\hline Distance to high forest $(\mathrm{m})$ & Distance to the nearest patch of woodland managed as high forest \\
\hline Distance to building $(\mathrm{m})$ & Distance to the nearest building \\
\hline Distance to dirt road $(m)$ & Distance to the nearest dirt road Distance \\
\hline to road $(m)$ & Distance to the nearest paved road \\
\hline Distance to building $(\mathrm{m})$ & Distance to the nearest inhabited building \\
\hline Cliff length $(m)$ & Length of cliff fronts within a radius of $330 \mathrm{~m}$ \\
\hline Isolated trees & Number of isolated trees within a radius of $330 \mathrm{~m}$ \\
\hline Edge length $(m)$ & Length of edges between woodland and grassland \\
\hline Open interspersion index & Number of boundaries between woodland and grassland crossed by two $N-S$ and $W-E$ transects of $660 \mathrm{~m}$ \\
\hline Interspersion index & Number of habitat boundaries crossed by two N-S and W-E transects of $660 \mathrm{~m}$ \\
\hline$\%$ coppice woodland & Percentage extent of coppice-managed woodland within a radius of $330 \mathrm{~m}$ \\
\hline \% Beech coppice & Percentage extent of coppice-managed woodland dominated by Beech within a radius of $330 \mathrm{~m}$ \\
\hline$\%$ high forest & Percentage extent of woodland managed as high forest within a radius of $330 \mathrm{~m}$ \\
\hline$\%$ broadleaved high forest & Percentage extent of broadleaved high forest within a radius of $330 \mathrm{~m}$ \\
\hline$\%$ conifer high forest & Percentage extent of conifer high forest within a radius of $330 \mathrm{~m}$ \\
\hline$\%$ broadleaved woodland & Percentage extent of broadleaved woodland within a radius of $330 \mathrm{~m}$ \\
\hline$\%$ total woodland & Percentage extent of any woodland type within a radius of $330 \mathrm{~m}$ \\
\hline$\%$ urban areas & Percentage extent of urban areas within a radius of $330 \mathrm{~m}$ \\
\hline$\%$ grassland & Percentage extent of grassland within a radius of $330 \mathrm{~m}$ \\
\hline$\%$ farmland & Percentage extent of intensive farmland within a radius of $330 \mathrm{~m}$ \\
\hline$\%$ rocky & Percentage extent of rocky outcrops and arid-sparse vegetation within a radius of $330 \mathrm{~m}$ \\
\hline Habitat diversity & Shannon index $x^{a}$ of habitat diversity (Krebs 1998) \\
\hline
\end{tabular}

${ }^{a}$ Calculated as: $\Sigma\left(p \log _{\mathrm{e}} p\right)$, where $p$ is the proportion of each habitat type. 